\title{
DNA DAMAGE AND REPAIR IN HUMAN TISSUES
}




\section{BASIC LIFE SCIENCES}

\section{Ernest H. Y. Chu, Series Editor}

The University of Michigan Medical School

Ann Arbor, Michigan

\section{Alexander Hollaender, Founding Editor}

\section{Recent volumes in the series:}

Volume 40 EXTRACHROMOSOMAL ELEMENTS IN LOWER EUKARYOTES

Edited by Reed B. Wickner, Alan Hinnebusch, Alan M. Lambowitz,

I. C. Gunsalus, and Alexander Hollaender

Volume 41 TAILORING GENES FOR CROP IMPROVEMENT:

An Agricultural Perspective

Edited by George Bruening, John Harada, Tsune Kosuge,

and Alexander Hollaender

Volume 42 EVOLUTION OF LONGEVITY IN ANIMALS: A Comparative Approach Edited by Avril D. Woodhead and Keith H. Thompson

Volume 43 PHENOTYPIC VARIATION IN POPULATIONS: Relevance to Risk Assessment Edited by Avril D. Woodhead, Michael A Bender, and Robin C. Leonard

Volume 44 GENETIC MANIPULATION OF WOODY PLANTS Edited by James W. Hanover and Daniel E. Keathley

Volume 45 ENVIRONMENTAL BIOTECHNOLOGY: Reducing Risks from Environmental Chemicals through Biotechnology Edited by Gilbert S. Omenn

Volume 46 BIOTECHNOLOGY AND THE HUMAN GENOME: Innovations and Impact Edited by Avril D. Woodhead and Benjamin J. Barnhart

Volume 47 PLANT TRANSPOSABLE ELEMENTS Edited by Oliver Nelson

Volume 48 HUMAN ACHONDROPLASIA: A Multidisciplinary Approach Edited by Benedetto Nicoletti, Steven E. Kopits, Elio Ascani, and Victor A. McKusick

Volume 49 OXYGEN RADICALS IN BIOLOGY AND MEDICINE Edited by Michael G. Simic, Karen A. Taylor, John F. Ward, and Clemens von Sonntag

Volume 50 CLINICAL ASPECTS OF NEUTRON CAPTURE THERAPY Edited by Ralph G. Fairchild, Victor P. Bond, and Avril D. Woodhead

Volume 51 SYNCHROTRON RADIATION IN STRUCTURAL BIOLOGY Edited by Robert M. Sweet and Avril D. Woodhead

Volume 52 ANTIMUTAGENESIS AND ANTICARCINOGENESIS MECHANISMS ॥ Edited by Yukiaki Kuroda, Delbert M. Shankel, and Michael D. Waters

Volume 53 DNA DAMAGE AND REPAIR IN HUMAN TISSUES Edited by Betsy M. Sutherland and Avril D. Woodhead 


\section{DNA DAMAGE AND REPAIR IN HUMAN TISSUES}

Edited by

Betsy M. Sutherland and Avril D. Woodhead

Brookhaven National Laboratory

Upton, New York 


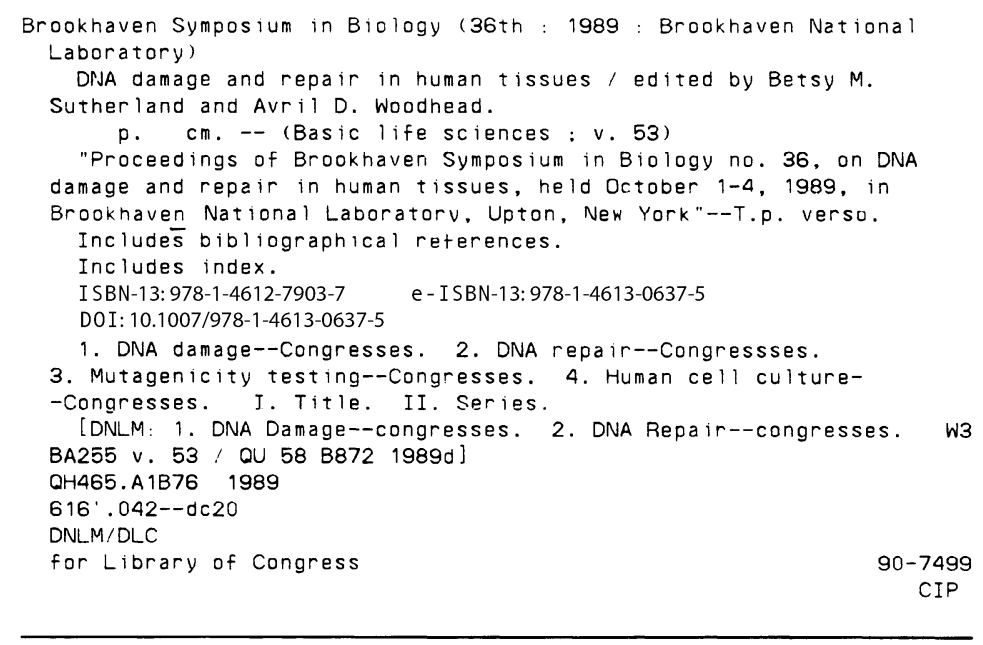

Proceedings of Brookhaven Symposium in Biology No. 36, on DNA Damage and Repair in Human Tissues. held October 1-4, 1989, at Brookhaven National Laboratory, Upton, New York

() 1990 Plenum Press, New York

Softcover reprint of the hardcover 1st edition 1990

A Division of Plenum Publishing Corporation

233 Spring Street, New York, N.Y. 10013

All rights reserved

No part of this book may be reproduced, stored in a retrieval system, or transmitted in any form or by any means, electronic, mechanical, photocopying, microfilming, recording, or otherwise, without written permission from the Publisher 
Physical and chemical agents in the environment damage the DNA of humans, and pose a major threat to human health today, and to the genetic integrity of human populations. Although studies on isolated DNA in vitro, on prokaryotes, on mammalian cells in culture, and on laboratory animals have provided essential background information, it is now possible to study DNA damage and repair in human tissues directly. New techniques of high sensitivity, especially those not requiring radioactive labeling have made possible quantitation of DNA damage and repair, as well as detection of residual, unrepaired DNA lesions.

In recent years, several investigators have taken up the challenge of studying damage and repair responses in humans, and we have chosen that work as the special focus of this Symposium. Major advances in understanding damage and responses in human skin, in blood cells and in human internal organs indicate three major themes. First, DNA damage levels in human tissues depend not only on the initial exposures, but also on the capapacity of that tissue for repair of the specific lesion type. Second, repair in human tissues may differ quantitatively and qualitatively from that in human cells in culture. Third, both the initial damage levels and the repair responses of humans vary over a wide range: variability is a signal characteristic of human populations!

The Symposium Committee, Symposium Coordinator, and Biology Department Business Manager thank first, the sponsors without whose generous support the meeting would not have been possible: Allergan Pharmaceuticals, Inc.; Bristol-Meyers Company; Department of Energy; Estee Lauder Inc.; Food and Drug Administration; Herbert Laboratories; Johnson \& Johnson; The Proctor \& Gamble Company; Risk Science Institute; and Westwood Pharmaceuticals. We also thank Ms. Kathy Folkers for outstanding work in manuscript processing; Ms. Folkers and Ms. Jean Frejka for assistance during the meeting; Ms. Judi Calace for her patience in manuscript photocopying, and all the staff of the Biology Department and Brookhaven National Laboratory who made the meeting proceed smoothly. We especially thank the many contributors who presented their exciting and, in many cases, unpublished data at the meeting, and to all the speakers who wrote their contributions for the volume promptly to allow for its early publication.

The Symposium Committee

Betsy M. Sutherland, Chair

Steven M. D'Ambrosio

Richard W. Gange

Richard B. Setlow

John C. Sutherland

Avril D. Woodhead

Symposium Coordinator

Helen Z. Kondratuk

Business Manager, Biology Department

Deborah M. Maresca 
CONTENTS

DNA LESION MEASUREMENT IN HUMAN TISSUES

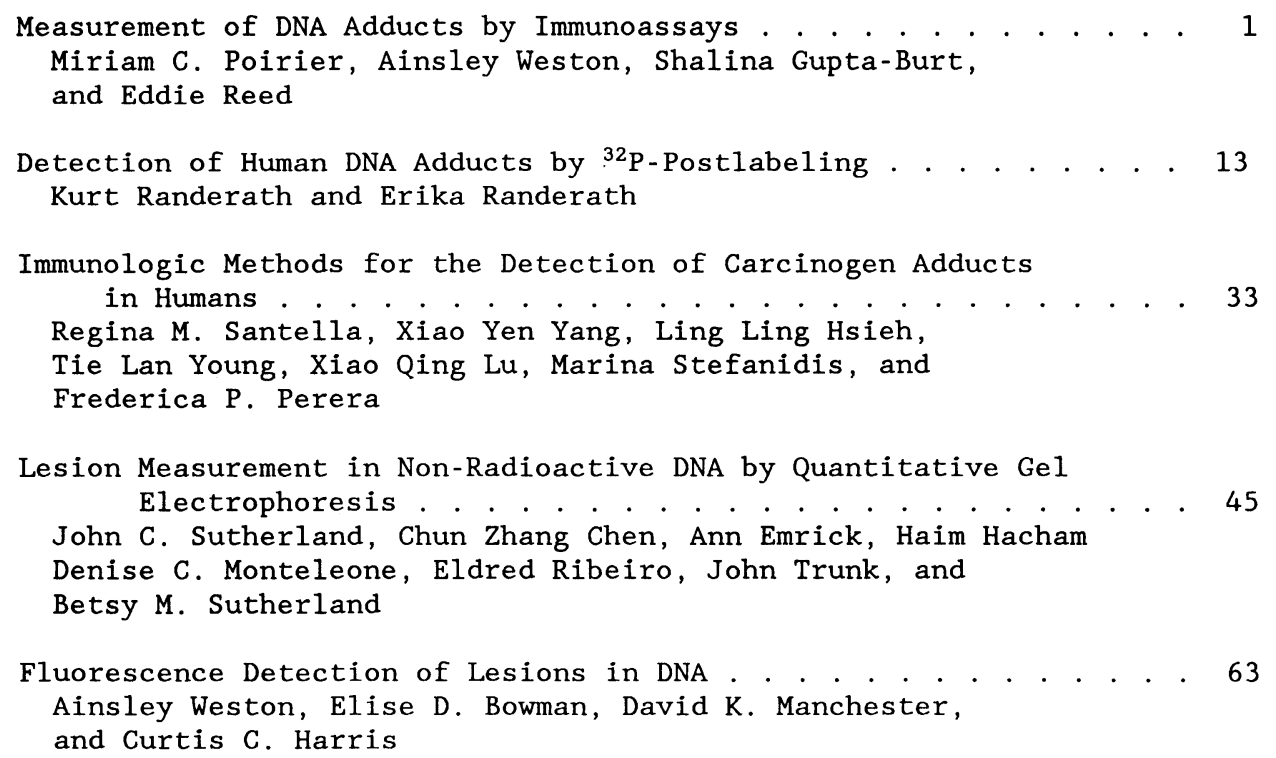

DAMAGE AND REPAIR IN SKIN

Solar Radiation Induced Skin Cancer and DNA Photoproducts

in Humans . . . . . . . . . . . . . . . . . . . . . . . . . . 83

Paul T. Strickland, Benjamin C. Vitasa, Magnus Bruze,

Edward A. Emmett, Sheila West, and Hugh R. Taylor

Defective DNA Repair in Humans: Clinical and Molecular Studies of Xeroderma Pigmentosum . . . . . . . . . . . . . . . . . . 95

Kenneth H. Kraemer, Saraswathy Seetharam, Michael M. Seidman, Anders Bredberg, Douglas Brash, Haywood L. Waters, Miroslava Protić-Sabljić, Gary Peck, John DiGiovanna, Alan Moshe11,

Robert E. Tarone, Gary Jones, Ram Parshad, and Katherine Sanford

5-MOP Induced Protection Against Epidermal DNA Damage by

Ultraviolet Radiation in Human Skin

Antony R. Young, Christopher S. Potten, Caroline A. Chadwick,

Gillian M. Murphy, and A. Jeffrey Cohen 
Variability in DNA Repair in Human Skin . . . . . . . . . . . . . 117 Steven E. Freeman

Effects of Chemicals on Photobiologic Reactions of Skin . . . . . 127 R. E. Davies, P. D. Forbes, and F. Urbach

Repair of 8-MOP Photoadducts in Human Lymphocytes . . . . . . . . . 137 F. Gasparro, P. Bevilacqua, D. Goldminz, and R. Edelson

\section{HUMAN SKIN: BIOCHEMISTRY AND MOLECULAR BIOLOGY}

DNA Damage and Repair in Human Skin: Pathways and Questions . . . . 149 Betsy M. Sutherland, Haim Hacham, Richard W. Gange, Daniel Maytum, and John C. Sutherland

Unscheduled DNA Synthesis in Human Skin . . . . . . . . . . . . . . 161 Herbert Hönigsmann

DNA Repair in Mammalian Tissues and Cells . . . . . . . . . . . . . 175 Hans E. Krokan, Lisbeth C. Olsen, Rein Aasland, Gunnar Volden, Guri Eggset, Bjornar Myrnes, Berit Johansen, Age Haugen, and Dag E. Helland

Damage Specific Mammalian Endonucleases . . . . . . . . . . . . . . 191 Bjorn-Ivar Haukanes, Paul W. Doetsch, Lisbeth C. Olsen, Ikramul Huq, Hans E. Krokan, and Dag E. Helland

MODEL SYSTEMS FOR HUMAN SKIN

Characteristics of DNA Excision Repair in Nondividing Xeroderma Pigmentosum Cells, Complementation Group C . . . . . . . . . 203 G. J. Kantor

Prospects for Epithelial Gene Therapy . . . . . . . . . . . . . . . 215 Elizabeth S. Fenjves, Joseph I. Lee, Jonathan A. Garlnick, David A. Gordon, David L. Williams, and Lorne B. Taichman

The Significance of DNA Damage and Repair Mechanisms in Health Risk Assessment . . . . . . . . . . . . . . . . . . . . . . . 225 Lorenz Rhomberg, Vicki L. Dellarco, William H. Farland, and Roger S. Cortesi

\section{DNA DAMAGE AND REPAIR IN HUMAN BLOOD CELLS}

Measurements of Genomic and Gene-Specific DNA Repair of Alkylation Damage in Cultured Human T-Lymphocytes . . . . . . 233 Jeanette N. Hartshorn, David A. Scicchitano, and Steven H. Robison

Peripheral Blood Leukocytes as a Surrogate Marker for Cisplatin Drug Resistance: Studies of Adduct Levels and the Repair Gene ERCC1 .. . . . . . . . . . . . . . . . . . . . . 251 Ricardo J. Parker, Miriam C. Poirier, Freida Bostick-Bruton, Justine Vionnet, Vilhelm A. Bohr, and Eddie Reed

Factors Which Affect DNA Repair in Human Lymphocytes . . . . . . . . 263 L. L. Larcom, M. E. Smith, and T. E. Morris 
Methyl Transferase Activity in Secondary Leukemia

Bernard Strauss, Daphna Sagher, Theodore Karrison,

Jeffrey Schwartz, Richard Larson, and Stephanie Williams

The Single Cell Gel Assay: A Sensitive Technique for Evaluating

Intracellular Differences in DNA Damage and Repair. . . . . . 291

R. R. Tice, P. W. Andrews, and N. P. Singh

\section{DETECTION AND ANALYSIS OF HUMAN MUTATIONS}

Cytogenetic Investigations of DNA Damage in Aging: A Twin Study . . 303 Betsy Hirsch

Studies of DNA Alterations in In Vivo Somatic Ce11 Mutations

in Humans . . . . . . . . . . . . . . . . . . . . . . . . . 315

Richard J. Albertini, Janice A. Nicklas, and J. Patrick O'Neill

Mechanisms of Induction of Specific Chromosomal Alterations . . . 329

R. Julian Preston

Unfolding Perspectives on the Genetic Effects of Human Exposures

to Radiation . . . . . . . . . . . . . . . . . . . . . . . . 337

James V. Neel

Effects of Caloric Restriction on the Maintenance of Genetic

Fidelity . . . . . . . . . . . . . . . . . . . . . 351

Ronald W. Hart, Angelo Turturro, Rex A. Pegram, and Ming W. Chou

\section{INTERNAL ORGANS}

Oncogenes and Tumor Suppressor Genes Involved in Human Lung

Carcinogenesis . . . . . . . . . . . . . . . . . . . . . . 363

Curtis C. Harris, Roger Redde1, Rama Modali, Teresa A. Lehman,

Deborah Iman, Mary McMenamin, Haruhiko Sugimura, Ainsley Weston, and Andrea Pfeifer

Activation of Carcinogens by Human Liver Cytochromes P-450 . . . . . 381

F. Peter Guengerich, Tsutomu Shimada, Masahiko Iwasaki,

Mary Ann Butler, and Fred F. Kadlubar

Repair of $0^{6}$-Methylguanine Damage in Normal Human Tissues . . . . . .397 Steven M. D'Ambrosio, Gulzar Wani, Mervyn Samue1,

Ruth Gibson-D'Ambrosio, and Altaf A. Wani

Repair of $0^{4}$-Alkylthymine Damage in Human Cells . . . . . . . . . . .417

Alataf A. Wani, Gulzar Wani, and Steven M. D'Ambrosio

Alkylation Repair in Human Tissues . . . . . . . . . . . . . . . . . 437

R. Montesano, J. Hall, M. Hollstein, N. Mironov, and C. P. Wild

PARTICIPANTS . . . . . . . . . . . . . . . . . . . . . . . 453

INDEX . . . . . . . . . . . . . . . . . . . . 459 